\title{
Long double stranded RNA is present in scrapie infected cells
}

\section{and tissues [version 1; peer review: 1 approved, 1 approved with reservations, 2 not approved]}

\section{Yervand E Karapetyan}

Department of Infectology, The Scripps Research Institute, Jupiter, FL, 33458, USA

\author{
V1 First published: 20 Nov 2012, 1:52 \\ https://doi.org/10.12688/f1000research.1-52.v1 \\ Latest published: 20 Nov 2012, 1:52 \\ https://doi.org/10.12688/f1000research.1-52.v1
}

\begin{abstract}
Despite decades of research efforts, the nature of the infectious agent causing scrapie and other Transmissible Spongiform

Encephalopathies (TSE) remains an enigma. The protein-only prion hypothesis posits that an abnormal conformer of a host protein is the infectious agent. Virus and virino theories include host-independent nucleic acids in the genome of the infectious agent, in addition to the protein component (a host protein in the case of virino, and a viral protein in the case of a virus).
\end{abstract}

Viral or sub-viral nucleic acids have long been sought in scrapie to explain the existence of multiple agent strains. Despite a plethora of different approaches to the search, no scrapie-specific nucleic acid sequences have been found in infected cells or tissues.

Most viruses induce synthesis of long double stranded RNA (dsRNA) during their replication in cells, and thus the presence of long dsRNA would be an indication of viral infection in cells. 12 monoclonal antibody against long dsRNA is a useful tool for easy screening of cells and tissues for the presence of suspected viral infection; however, this antibody has not previously been used for testing of scrapie infected tissues.

Here, we present evidence for long dsRNA in scrapie infected cells and tissues. Such dsRNA is also found in scrapie free tissue culture cells. We believe this may be the first evidence of viral infection in scrapie susceptible and infected cells.

\section{Open Peer Review}

\begin{tabular}{|c|c|c|c|c|}
\hline & 1 & 2 & 3 & 4 \\
\hline version 1 & $x$ & $?$ & $\checkmark$ & X \\
\hline 20 Nov 2012 & view & view & view & view \\
\hline
\end{tabular}

1. Hubert Laude, Virologie Immunologie

Moléculaires, Jouy-en-Josas, France

2. Robert Somerville, The Roslin Institute, University of Edinburgh, UK

Karen Brown, University of Edinburgh, Edinburgh, UK

3. Igor Zaitsev, The City University of New York, New York, NY, USA

4. Pascal Leblanc, Unite de Virologie Humaine, Ecole Normale Superieure de Lyon, 69364

Lyon Cedex 07, France

Any reports and responses or comments on the article can be found at the end of the article. 


\section{Associated Correspondence}

Zaitsev IV, Chen L, Boydston-White S et al. » The prion dilemma confounding science educators, F1000Research 2013, 2:4 (https://doi.org/10.12688/f1000research.2-4.v1)

Corresponding author: Yervand E Karapetyan (yervandkar@gmail.com)

Competing interests: No competing interests were disclosed.

Grant information: The author(s) declared that no grants were involved in supporting this work.

Copyright: ๑ 2012 Karapetyan YE. This is an open access article distributed under the terms of the Creative Commons Attribution License, which permits unrestricted use, distribution, and reproduction in any medium, provided the original work is properly cited. Data associated with the article are available under the terms of the Creative Commons Zero "No rights reserved" data waiver (CC0 1.0 Public domain dedication).

How to cite this article: Karapetyan YE. Long double stranded RNA is present in scrapie infected cells and tissues [version 1; peer review: 1 approved, 1 approved with reservations, 2 not approved] F1000Research 2012, 1:52

https://doi.org/10.12688/f1000research.1-52.v1

First published: 20 Nov 2012, 1:52 https://doi.org/10.12688/f1000research.1-52.v1 


\section{Editorial note:}

Please note that the refereeing status of this article was changed from "indexed" to "[v1; ref status: not approved 2, approved with reservations 1, approved 1]".

When this article was first published, F1000Research was still in its beta phase; during this period articles that received any two of "Approved" or "Approved with Reservations" statuses from the reviewers were labelled as "indexed". When the journa was formally launched in January 2013, the requirements for indexing were tightened, and only articles that are given either two "Approved" or one "Approved" plus two "Approved with Reservations" statuses by the reviewers are labelled "indexed". The new criteria for "indexing" can still be met in the future if a new revised version receives the necessary approval status from the reviewers.

\section{Introduction}

Transmissible Spongiform Encephalopathies are rare neurodegenerative brain disorders in both humans (e.g. Creutzfeldt-Jakob disease and Kuru) and animals (Scrapie in sheep, Bovine Spongiform Encephalopathy in cows and Chronic Wasting Disease in deer and elk), characterized by a long incubation period after initial infection. Once symptoms become apparent in humans, the disease progresses inevitably to death within weeks or months, and, to date, no treatment or early preclinical diagnostics are available.

The nature of the infectious agent causing these disorders remains unexplained. The most advertised, but not proven to date, prion protein-only theory simply states that the agent is nothing more than a misfolded host glycoprotein called prion protein ${ }^{1}$. How this single host protein "encodes" the numerous agent strains that have distinct clinical and pathological features remains to be demonstrated by prion scientists. The infectivity of recombinant prion protein misfolded in a test tube in a mixture with RNA and lipid and later injected into the animal brains was demonstrated a few years ago but was never reproduced independently in a laboratory free of contamination ${ }^{2}$. The statement that cell free replication of TSE infectivity in a test tube excludes the possibility of the agent being a virus $^{3}$ ignores the well known fact of human poliovirus replication in a cell free system ${ }^{4}$.

On the other hand, virino and virus theories claim that hostindependent nucleic acid is the genome of the infectious agent ${ }^{5}$. Virus theory states that the agent is a virus that has not been discovered yet ${ }^{6}$, while virino theory postulates that the agent is a chimera composed of a host-independent nucleic acid (the genome of the agent) and a host protein, probably the prion protein that protects the genome ${ }^{7}$. Obviously, nucleic acid-containing theories explain the existence of many agent strains since nucleic acid sequences are the only molecules known to-date that encode phenotypes of all living organisms including microbes, with the smallest among them being the nucleic acids of viroids and satellite RNAs of plant viruses (only few hundred non protein coding nucleotides) ${ }^{8}$. Despite decades of research efforts, no TSE-specific nucleic acid sequences have been found yet ${ }^{9}$, leading to the popular conclusion among many scientists that no such nucleic acid exists.
While many different approaches were undertaken to hunt for the elusive viral or subviral nucleic acid, surprisingly, the simplest and easiest of them was not employed. J2 monoclonal antibody recognizes double-stranded RNA (dsRNA) provided that the length of the helix is $\geq 40 \mathrm{bp}^{10}$. Importantly, dsRNA-recognition is independent of the sequence and nucleotide composition of the antigen. All naturally occurring dsRNA investigated up to now (40-50 species) as well as poly(I)•poly(C) and poly(A)•poly(U) have been recognized by $\mathrm{J} 2{ }^{11}$. In a systematic study of different viruses, $\mathrm{J} 2$ detected dsRNA in cells infected with positive-strand RNA viruses, doublestranded RNA viruses and DNA viruses, but not negative-strand RNA viruses ${ }^{12}$. This shows that most viruses induce synthesis of long double stranded RNA (dsRNA) during their replication in cells that can be detected by J2. Therefore, the presence of long dsRNA would be an indication of viral infection in cells. J2 antibody has not been used for testing of scrapie infected tissues and the first attempt is made in the present work.

\section{Methods/results}

\section{Immunofluorescence}

JFH1 Huh7 cells (human hepatoma cells harboring hepatitis C replicon) and Huh7.5 cells (human hepatoma cells free of replicon) were used as a positive (JFH1 Huh7) and negative (Huh7.5) control for dsRNA in immunofluorescence detection experiments (Figure 1a) when probing PK1 cells (a clone of mouse neuroblastoma N2A cells) and RML (Rocky Mountain Laboratory strain of mouse scrapie) infected PK1 (RML/PK1) cells with J2 antibody (mouse monoclonal from Englsih and Scientific Consulting) (Figure 1b). A secondary anti-mouse antibody labeled with Alexa 488 fluorophore is used to visualize $\mathrm{J} 2$ binding sites. dsRNA was detected in the cytoplasm of both PK1 and RML/PK1 cells (Figure 1b). The signal was abolished after RNase A (Invitrogen) treatment at $50 \mu \mathrm{g} / \mathrm{ml}$ in $50 \mathrm{mM} \mathrm{NaCl}$ as it is shown for PK1 cells in Figure 1c.

\section{Immunoblotting}

J2 antibody was also used for immunoblotting of dsRNA, as described previously ${ }^{13}$. Crude RNA extracts from JFH1 Huh7, Huh7.5, PK1 and PK1/RML cells were size separated using nondenaturing TBE-polyacrylamide gel, transferred to positively charged Nylon membrane and immunoblotted with J2. Secondary anti-mouse antibody linked to HRP (horseradish peroxidase) and a substrate for it was used for visualization of the blots. Results showed the presence of replication intermediate-RI (upper part of the gel slot, black arrow) and replicative form-RF (seen as a strong band bellow RI, dark blue arrow) in JFH1 Huh7 that were both absent in Huh7.5 (Figure 2). In PK1 and RML/PK1 in addition to dsRNA in the upper part of the gel slots several bands were seen including a duplet with a molecular weight much lower than that of RF of HCV replicon (Figure 2).

\section{Immunohistochemistry (IHC)}

J2 antibody was recently used for successful detection of viral dsRNA in formalin-fixed paraffin-embedded tissues ${ }^{14}$. Here an attempt was made to detect dsRNA in 22L scrapie infected mouse brains fixed in Carnoy's solution and embedded in paraffin. Proteinase $\mathrm{K}$ treatment was used as described ${ }^{15}$, followed by inhibition in glycine $(2 \mathrm{mg} / \mathrm{ml}$ in nanopure water) and short post-fixation in 
A

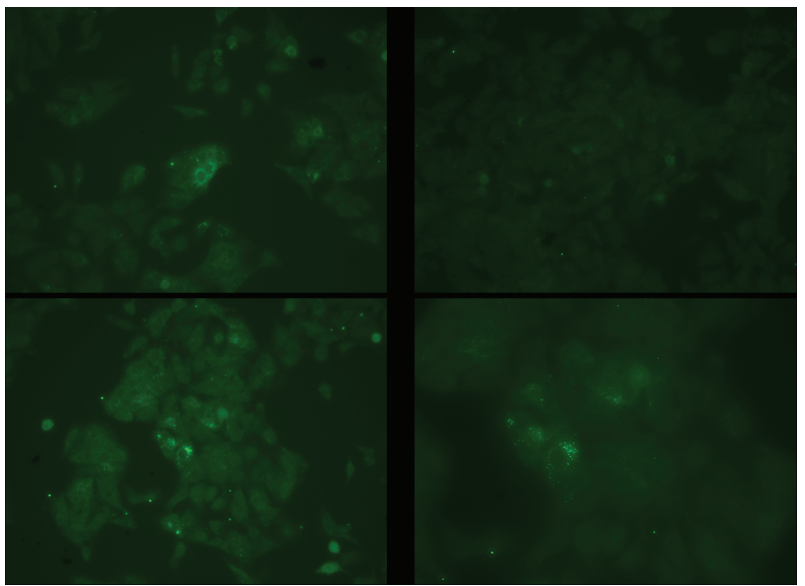

B

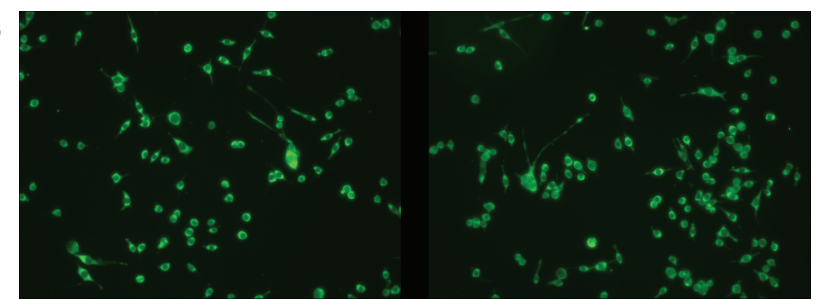

C
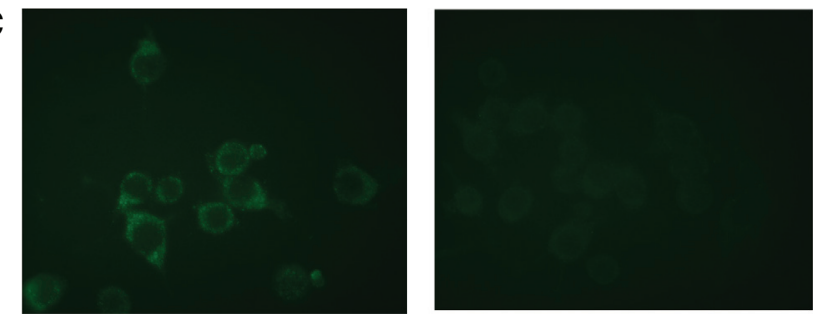

Figure 1. dsRNA is detected with J2 antibody via indirect immunofluorescence. A secondary anti-mouse antibody labeled with Alexa 488 fluorophore is used to visualize J2 binding sites. (a). In contrast to the absence of green signal in Huh7.5 cells, JFH1 Huh7 cells show punctuate staining in some of them which harbor hepatitis $C$ replicon. (b). dsRNA is detected in both scrapie free PK1 cells and RML scrapie infected RML/PK1 cells. (c). dsRNA disappears from PK1 cells after treatment with RNase A at low salt conditions where it destroys both single stranded and double stranded RNA.

formalin to expose dsRNA for detection. IHC detection of dsRNA in brains using $\mathrm{J} 2$ was done with a secondary system described in ref. ${ }^{6}$. Uninfected $\mathrm{C} 57 \mathrm{Bl} / 6$ mice brains were used as control and brains of terminally sick C57B1/6 mice infected with 22L strain of mouse scrapie were used for the experiment. As a result, dsRNA was detected in scrapie-infected brain predominantly in the cytoplasm of large neurons in the cortex (Figure 3a) and brainstem (Figure 3b). Nuclear staining was also detected in some neurons of the infected brain. In uninfected brain, nuclear staining of some Purkinje cells was detected in the cerebellum (Figure 3c). Otherwise the staining in the control brain was largely absent.

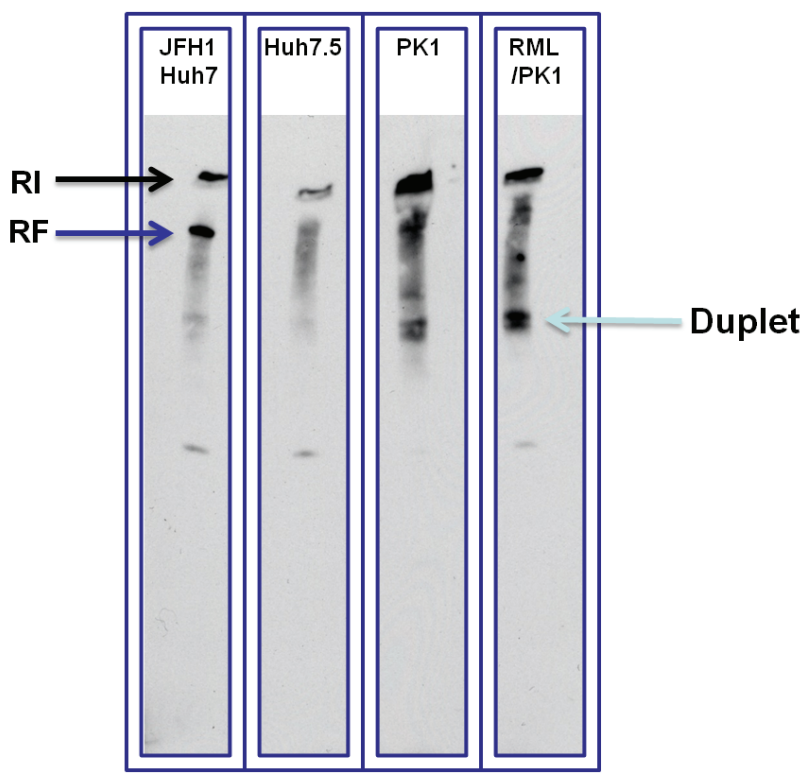

Figure 2. Huh7.5 cells were used as a negative control and JFH1 Huh7 cells as a positive control for dsRNA. Two bands of dsRNA were detected in JFH1 Huh7 (RI and RF shown by black and dark blue arrows). In PK1 and PK1/RML cells several bands of dsRNA are detected including top ones in the gel slots corresponding to long dsRNA that did not enter the gel. A much lower duplet band could be seen in both specimens. In addition there are several bands in between the duplet and the upper most band.

\section{Discussion}

Data presented here shows dsRNA is detectable by J2 antibody using immunofluorescence in scrapie susceptible and scrapie infected tissue culture cells. In contrast, it seems that only scrapie infected brain has dsRNA in the cytoplasm of some neurons. Immunoblotting shows long as well as short dsRNA bands in scrapie susceptible and scrapie infected tissue culture cells (Figure 2). Long dsRNA is not present in uninfected mammalian cells and can only be present as a result of viral infection. Therefore long dsRNA presence in scrapie susceptible as well as scrapie infected cells is a strong indication of viral infection of these cells. Shorter dsRNA bands also detected in these cells might point to the presence of subviral nucleic acids ${ }^{16}$. These data provide an experimental basis for speculation that scrapie agent could be a satellite nucleic acid of a silent and persistent virus that infects susceptible host cells. A virusoid (satellite RNA) in order to replicate would need a helper virus to be in every species and cell that is susceptible to infection. Gajdusek proposed such scenario four decades ago: "These viruses could be associated or satellite viruses which serve to activate or are themselves activated by some helper virus latent in the susceptible host" ${ }^{\prime \prime}$.

In analogy to plant satellite RNAs ${ }^{18}$, scrapie agents' nucleic acid can function via RNAi to silence host neuronal survival genes (e.g. bcl-2 anti-apoptotic group genes) and cause lethal disease due to its homology with host gene sequences. 


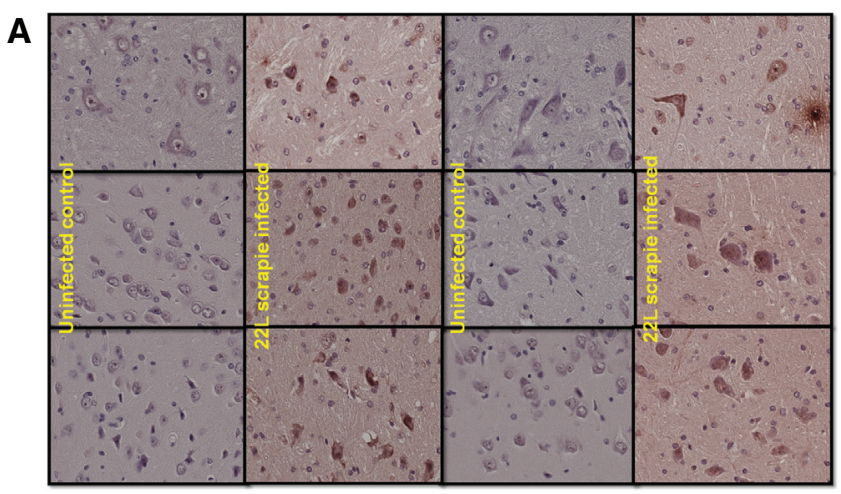

B

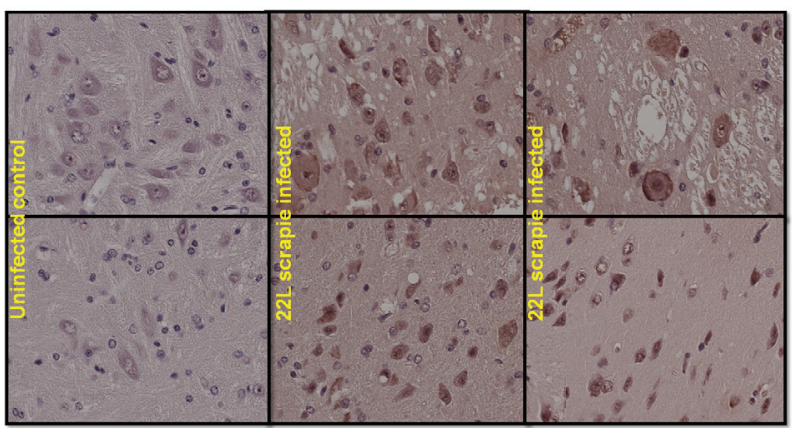

C

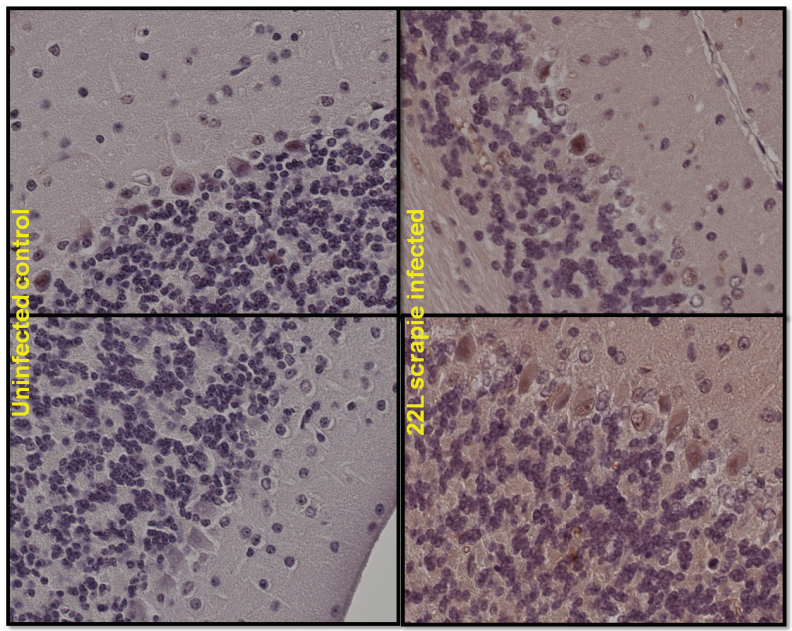

Figure 3. IHC detection of dsRNA in brains using $\mathbf{J 2}$ was done with a secondary system described in ref. ${ }^{5}$. Uninfected C57BI/6 mice brains were used as control and brains of terminally sick mice infected with $22 \mathrm{~L}$ strain of mouse scrapie were used for the experiment. (a). Mostly cytoplasmic and some nuclear staining can be seen in cortical neurons of infected brain. While staining is absent in uninfected control brain. (b). Similar staining pattern is observed in brainstem especially in large neurons. And again staining is absent in parallel uninfected control sections. (c). Some nuclei of Purkinje cells are stained in the cerebellum of both uninfected control and 22L infected brain.

\section{Conclusion}

For the first time experimental evidence is provided for the presence of long dsRNAs in scrapie infected cells and tissues. This is the strongest argument presented so far for the existence of a virus in scrapie infected cells and tissues. These molecules deserve sequencing and characterization of their relationship to scrapie agent and disease.

\section{Competing interests}

No competing interests were disclosed.

\section{Grant information}

The author(s) declared that no grants were involved in supporting this work. 


\section{Aknowledgments}

I thank Dr. Corinne Lasmezas for supervising and supporting my work at Scripps Florida. I am grateful to Dr. Timothy Tellinghuisen, from whom at his lab meeting presentation at Scripps Florida I learnt about the existence of $\mathrm{J} 2$ antibody and who sincerely provided human hepatoma cells with and without $\mathrm{HCV}$ replicon. I greatly appreciate Franco Sferrazza's expert help in setting up the immunoblotting experiment.
1. Prusiner SB: Novel proteinaceous infectious particles cause scrapie. Science. 1982; 216(4542): 136-44

PubMed Abstract | Publisher Full Text

2. Karapetyan Y: Is Recombinant Prion Protein by Itself Infectious? Reference Source

3. Klingeborn M, Race B, Meade-White KD, et al.: Lower specific infectivity of protease-resistant prion protein generated in cell-free reactions. Proc Nat Acad Sci USA. 2011; 108(48): E1244-53. PubMed Abstract | Publisher Full Text | Free Full Text

4. Karapetyan YE: Viruses do replicate in cell-free systems. Proc Natl Acad Sci USA. 2012; 109(8): E461.

PubMed Abstract | Publisher Full Text | Free Full Text

5. Dickinson AG, Outram GW: Genetic aspects of unconventional virus infections: the basis of the virino hypothesis. Ciba Found Symp. 1988; 135: 63-83. PubMed Abstract

6. Manuelidis L: A $\mathbf{2 5} \mathbf{n m}$ virion is the likely cause of transmissible spongiform encephalopathies. J Cell Biochem. 2007; 100(4): 897-915. PubMed Abstract | Publisher Full Text

7. Kimberlin RH: Scrapie agent: prions or virinos? Nature. 1982; 297(5862): 107-8. PubMed Abstract | Publisher Full Text

8. Elena SF, Dopazo J, de la Peña M, et al:: Phylogenetic analysis of viroid and viroid-like satellite RNAs from plants: a reassessment. $J$ Mol Evol. 2001; 53(2): 155-9.

PubMed Abstract | Publisher Full Text

9. Simoneau S, Ruchoux MM, Vignier N, et al:: Small critical RNAs in the scrapie agent. Nature Precedings. 2009.

Reference Source

10. Schönborn J, Oberstrass J, Breyel E, et al: Monoclonal antibodies to double-stranded
RNA as probes of RNA structure in crude nucleic acid extracts. Nucleic Acids Res. 1991; 19(11): 2993-3000.

PubMed Abstract | Publisher Full Text | Free Full Text

11. http://www.engscicons.de/monoclonal2005_ger/J2_desc2005.htm.

12. Targett-Adams $P$, Boulant $S$, McLauchlan J: Visualization of double-stranded RNA in cells supporting hepatitis C virus RNA replication. $J$ Virol. 2008; 82(5): 2182-95.

PubMed Abstract | Publisher Full Text | Free Full Text

13. Veliceasa $D$, Enünlü N, Kós $P B$, et al:: Searching for a new putative cryptic virus in Pinus sylvestris L. Virus Genes. 2006; 32(2): 177-86. PubMed Abstract | Publisher Full Text

14. Richardson SJ, Willcox A, Hilton DA, et al: Use of antisera directed against dsRNA to detect viral infections in formalin-fixed paraffin-embedded tissue. $J$ Clin Virol. 2010; 49(3): 180-5.

PubMed Abstract | Publisher Full Text

15. Karapetyan YE, Saá $P$, Mahal SP, et al.: Prion strain discrimination based on rapid in vivo amplification and analysis by the cell panel assay. PLOS One. 2009; 4(5): e5730.

PubMed Abstract | Publisher Full Text | Free Full Text

16. Owens RA, Diener TO: RNA intermediates in potato spindle tuber viroid replication. Proc Natl Acad Sci USA. 1982; 79(1): 113-7. PubMed Abstract | Publisher Full Text | Free Full Text

17. Gajdusek DC: Spongiform virus encephalopathies. J Clin Pathol Suppl (R Coll Pathol). 1972; 6: 78-83.

PubMed Abstract | Publisher Full Text | Free Full Text

18. Smith NA, Eamens AL, Wang MB: Viral small interfering RNAs target host genes to mediate disease symptoms in plants. PLoS Pathog. 2011; 7(5): e1002022. PubMed Abstract | Publisher Full Text | Free Full Text 


\section{Open Peer Review}

\section{Current Peer Review Status: $\mathrm{X} ? \checkmark \mathrm{X}$}

Version 1

Reviewer Report 15 February 2013

https://doi.org/10.5256/f1000research.223.r772

(C) 2013 Leblanc P. This is an open access peer review report distributed under the terms of the Creative Commons Attribution License, which permits unrestricted use, distribution, and reproduction in any medium, provided the original work is properly cited.

\section{Pascal Leblanc}

LaboRetro INSERM U758, Unite de Virologie Humaine, Ecole Normale Superieure de Lyon, 69364 Lyon Cedex 07, France

The present study of Karapetyan indicates that dsRNAs are detected in tissues and cells infected with the scrapie agent. For this purpose Karapetyan used the $\mathrm{J} 2$ monoclonal antibody that recognizes dsRNAs and tested this antibody in different experimental conditions i.e. Huh7.5 hepatocyte cells in the presence (positive control) or absence (negative control) of HCV infection. Similarly, he tested the presence of dsRNA on the Neuroblastoma N2a PK1 cellular model infected or not by the RML scrapie agent strain, and finally he investigated if dsRNAs can be detected in the brain of scrapie infected animals.

As expected, the data indicated a positive signal in HCV infected cells, whereas no signal was observed in non-infected cells. The panel for Huh7.5 non-infected cells is not depicted. Additional immunofluorescence data or an immunoblotting data confirming the HCV replication in the infected cells should be added.

Similarly, the N2a PK1 cells like RML infected PK1 cells were found to be positive for dsRNAs, indicating that no difference is detected between scrapie infected and non-infected cells. It should be noted that my group previously found that N2a cells replicate a murine leukemia endogenous retrovirus (Neuroblastoma endogenous retrovirus) that does not modulate scrapie replication and release (Alais et al. 2008). We also found that these cells express high levels of Intra A cisternal Particles (IAP) endogenous retroviruses and that IAP-Gag proteins co-localize and co-fractionate with PrP (Alais et al. 2008). Similar data was also obtained by the group of Laura Manuelidis ( Manuelidis et al.1995). All these endogenous retroviruses produce structured dsRNAs that could be detected by this antibody. So in this context, the detection of dsRNA in these cells are expected. It should be considered that the persistence of a signal in scrapie infected cells after RNAse treatment can be due to the interaction of of PrPSc with these viral RNAs.

The last piece of data indicates that a dsRNA signal is detected in brain of infected mouse whereas no signal was observed in non-infected control mouse. This result is interesting and should be extensively investigated. If we think in term of virology, many hypotheses can be proposed for this. My group and others have found that PrPC displays some antiviral properties. We could 
imagine that the decrease of PrPC could favor the expression and replication of endogenous viruses (especially endogenous retroviruses). On the other hand, the scrapie infection can also modulate the replication of endogenous viruses. Micro RNAs (miRNAs) can also be deregulated during scrapie infection and miRNAs (or pre-miRNAs) could be detected with this $J 2$ antibody. So in this context and through the data presented here, we can not say that "this is the strongest argument presented so far for the existence of a virus in scrapie infected cells and tissues". Many other alternatives can be suggested.

The results presented here are very preliminary and much work will be required to substantiate these observations and establish their relevance.

Competing Interests: No competing interests were disclosed.

\section{I confirm that I have read this submission and believe that I have an appropriate level of expertise to state that I do not consider it to be of an acceptable scientific standard, for reasons outlined above.}

Author Response 13 Dec 2013

Yervand Karapetyan, The Scripps Research Institute, Jupiter, FL, USA

"The panel for Huh7.5 non-infected cells is not depicted."

This panel is shown, and is the one on the right upper corner of Figure $1 \mathrm{~A}$.

"Additional immunofluorescence data or an immunoblotting data confirming the HCV replication in the infected cells should be added."

Immunoblotting data confirming the HCV replication in the infected cells is shown in Figure 2. [Two bands of dsRNA are detected in JFH1 Huh7 (RI and RF shown by black and dark blue arrows) which are absent in Huh7.5 cells].

"All these endogenous retroviruses produce structured dsRNAs that could be detected by this antibody."

All these retroviruses produce only partial dsRNAs, where dsRNA parts are not longer than 40bp, therefore they cannot be detected by the 12 antibody. If Dr Leblanc has published or unpublished data proving the contrary, I would sincerely ask him to recommend this work to us. Subsequently his next sentence - "So in this context, the detection of dsRNA in these cells are expected. - is also false, because the detection of dsRNA in these cells was unexpected and is not due to the presence of retroviruses, but is most likely due to the replication of a virus of non-retroviral origin.

"It should be considered that the persistence of a signal in scrapie infected cells after RNAse treatment can be due to the interaction of of PrPSC with these viral RNAs." There is no such data shown in the paper. Instead it is shown in Figure 1C that dsRNA disappears from PK1 uninfected with scrapie cells after treatment with RNase A.

"Micro RNAs (miRNAs) can also be deregulated during scrapie infection and miRNAs (or pre-miRNAs) could be detected with this $J 2$ antibody". 
miRNAs can indeed be deregulated during scrapie infection, but they or pre-miRNAs cannot be detected by $\mathrm{J} 2$ antibody, since there are no dsRNA stretches longer than $40 \mathrm{bp}$ in either of them. miRNAs are no longer than 23-24 nucleotides, and they are not perfectly double stranded, but are only partially double stranded. The same applies to pre-miRNAs that are longer in length but do not have dsRNA stretches of longer than $40 \mathrm{bp}$ in them.

"So in this context and through the data presented here, we cannot say that "this is the strongest argument presented so far for the existence of a virus in scrapie infected cells and tissues". Many other alternatives can be suggested."

There cannot be many other alternatives suggested, since no retroviral sequences can be detected by $\mathrm{J} 2$, for the reasons outlined above. And indeed we can say that this is the strongest argument presented so far for the existence of a virus of nonretroviral origin in scrapie infected cells and tissues.

We would welcome Dr. Leblanc's response to our clarifications on his comments.

Competing Interests: No competing interests

Reviewer Response 19 Dec 2013

PASCAL LEBLANC, Unite de Virologie Humaine, Ecole Normale Superieure de Lyon, 69364 Lyon Cedex 07, France

Specificity of this antibody should be controlled. If Dr Karapetyan is right, immunofluorescence experiments carried out on cells expressing a MuLV retrovirus (for example 293T cells expressing or not a murine retrovirus like MoMuLV and NIH3T3 infected or not by MoMuLV ) should be negative...You have just to test the specificity of this antibody. No, I have no published or unpublished data proving the contrary.

My major concern is just the specificity of this antibody, and the fact that N2a cells express endogenous retroviruses. If immunofluorescences are negative in suggested cells, the message of Karapetyan will be stronger.

Competing Interests: No competing interests were disclosed.

\section{Author Response 09 Oct 2017}

Yervand Karapetyan, The Scripps Research Institute, Jupiter, FL, USA

In fact, I found the answer to the question posed by Dr. LeBlanc in the published literature. That is - whether endogenous retroviruses expressed in N2a cells can be responsible for the positive staining with $\mathrm{J} 2$ anti-dsRNA antibody observed in this paper. And the answers is no, endogenous infectious Murine Leukemia Virus (MuLV), a retrovirus amplified and produced in mouse Neuro-2a neuroblastoma cells is not producing dsRNA detectable by $\mathrm{J} 2$.

Indeed all Neuro-2a cells are producing infectious MuLV (

https://www.ncbi.nlm.nih.gov/pubmed/16550601) but when they are not infected with 
another virus of non retroviral origin, they are negative for $\mathrm{J} 2$ staining and are stained only when they are infected with a virus of non retroviral origin (

https://www.ncbi.nlm.nih.gov/pmc/articles/PMC4206540/\#SUP1).

So, the cells used in our experiments, which are susceptible to scrapie infection, are infected with a virus of non retroviral origin in addition to endogenous MuLV and this is the first evidence for the replication of such a non retroviral virus in scrapie susceptible as well as scrapie infected cells.

Competing Interests: No competing interests.

Reviewer Report 28 November 2012

https://doi.org/10.5256/f1000research.223.r387

(c) 2012 Zaitsev I. This is an open access peer review report distributed under the terms of the Creative Commons Attribution License, which permits unrestricted use, distribution, and reproduction in any medium, provided the original work is properly cited.

\section{Igor Zaitsev}

Science Department, Borough of Manhattan Community College, The City University of New York, New York, NY, USA

This paper presents interesting data on a fact that has been ignored by many researchers working on the transmissible spongiform encephalopathies (TSEs) and that is the presence of virus-like particles in the experimental animal tissue samples.

For the first time, the $\mathrm{J} 2$ monoclonal antibodies against long dsRNA had been used in the scrapie infected tissue. The accumulations of the antibodies in cortical neurons of the infected brain seem to be present in contrast to the controls. This fact itself deserves attention and suggests further testing of the $\mathrm{J} 2$ monoclonal antibodies in TSEs. In the discussion section, the author suggests the satellite nature of the infectious agent without supporting evidence that comes from his experimental data. Nevertheless, it is still a viable reminder that such a possibility should not be ruled out at the present development in the field of TSEs research. The experimental approach that had been used is unique and deserves further experimental trails by other investigators since more has to be done to identify the nature of the infectious agent of TSEs. This work could be a valuable contribution to the discovery of its identity.

Competing Interests: No competing interests were disclosed.

I confirm that I have read this submission and believe that I have an appropriate level of expertise to confirm that it is of an acceptable scientific standard. 
Reviewer Report 27 November 2012

https://doi.org/10.5256/f1000research.223.r386

(C) 2012 Somerville $\mathbf{R}$ et al. This is an open access peer review report distributed under the terms of the Creative Commons Attribution License, which permits unrestricted use, distribution, and reproduction in any medium, provided the original work is properly cited.

\section{Robert Somerville}

Neurobiology Division, The Roslin Institute, University of Edinburgh, UK

Karen Brown

The Roslin Institute and Royal (Dick) School of Veterinary Sciences, University of Edinburgh, Edinburgh, UK

This paper describes the use of the $\mathrm{J} 2$ monoclonal antibody to detect differences in the amount of double stranded RNA between uninfected and TSE (prion) infected brain and cell cultures.

The antibody was used to detect dsRNA by immunofluorescence in control JFH1 cells and cells infected with hepatitis $C$, and in PK1 cells that were or were not infected with a TSE strain. In this experiment the detection of antigen in the JFH1 cells was poorly demonstrated. However the PK1 cells showed high levels of immune-reactivity whether or not they were infected. Staining was reduced by RNAase A treatment, although in this case the untreated control showed poorer staining. Crude undenatured RNA extracts from these cells were also run on gels and immunoblotted with the $\mathrm{J} 2$ antibody. The antibody detected bands in the hepatitis $\mathrm{C}$ infected cells which were absent from the uninfected cells. The banding pattern differed between the Huh 7.5 cells and the PK1 cells. Although there are minor differences between uninfected and infected PK1 cell extracts no major difference was detected or commented on by the author.

In the third experiment control and TSE infected brain sections were subjected to immunohistochemistry using the $\mathrm{J} 2$ antibody. In this experiment some differences are observed between the control and TSE infected samples. However there are some weaknesses in presentation which compromise the assessment of these images. Firstly figure $3 \mathrm{~A}$ is difficult to interpret because the colour of the sections from control brain are markedly different from those from the infected animal, which could be misleading. The author could consider trying to do some form of quantification of the numbers of positive cells within a defined field using a software package such as image J. Figure 3B is a better panel but again the colour balance between the negative and positive panels differs. Figure $3 \mathrm{C}$ is less convincing because the images are again poorly presented. It would have been helpful to present them with a similar and lighter colour balance, and with the same area in the same orientation. The use of the term "some cells" is imprecise and could be improved by conducting some quantification, e.g. by counting positive cells in a defined area (blind). Scale bars should be included throughout.

In summary, the results presented in the paper show $\mathrm{J} 2$ binding to antigen in cells and brain sections. There are differences between uninfected and hepatitis $C$ infected cells and some indication of differences between control and TSE infected brain. However the results are very preliminary and much work will be required to substantiate these observations and establish their relevance. 
Competing Interests: No competing interests were disclosed.

We confirm that we have read this submission and believe that we have an appropriate level of expertise to confirm that it is of an acceptable scientific standard, however we have significant reservations, as outlined above.

Reviewer Report 22 November 2012

https://doi.org/10.5256/f1000research.223.r385

(C) 2012 Laude H. This is an open access peer review report distributed under the terms of the Creative Commons Attribution License, which permits unrestricted use, distribution, and reproduction in any medium, provided the original work is properly cited.

\section{Hubert Laude}

Institut National de la Recherche Agronomique (INRA), Virologie Immunologie Moléculaires, Jouyen-Josas, France

This paper is scientifically poor. The author's claim is based only on the data presented in figure 3, which is far from being convincing. What's more, the data presented in Figures 1 and 2 (the documentation of the specificity of the $\mathrm{J} 2$ antibody) clearly show the presence of long ds RNA in both prion-infected and uninfected cell cultures.

Competing Interests: No competing interests were disclosed.

I confirm that I have read this submission and believe that I have an appropriate level of expertise to state that I do not consider it to be of an acceptable scientific standard, for reasons outlined above.

Author Response 22 Nov 2012

Yervand Karapetyan, Histopathology Laboratory, Oncological Dispensary, Azerbaijan

I thank Dr Laude for his comments.

The claim "Long double stranded RNA is present in scrapie infected CELLS and TISSUES" is based on data shown in all 3 figures. As far as cell cultures are concerned, indeed long dsRNA is present in both scrapie free and scrapie infected cells and this in no way undermines the claim "Long double stranded RNA is present in scrapie infected CELLS...". The brain tissue experiment is a single experiment and the purpose here was to do a pilot test and that is what the results show.

Competing Interests: No competing interests were disclosed. 


\section{Comments on this article}

\section{Version 1}

Reader Comment 23 Feb 2016

Anita Bandrowski, University of California, San Diego, USA

Dear Authors,

In testing a new tool for methods review, I detected the following research resources in your paper which did not contain the RRID (Research Resource IDentifier). As discussed in the instruction to authors, please consider adding these to the final version of your paper.

RRIDs are universal and persistent product codes and are used for antibodies, software tools and model organisms, see instructions to authors:

http://f1000research.com/for-authors/article-guidelines/research-notes

Please verify the accuracy of the RRIDs below:

Needs attention, no match based on information provided:

$\mathrm{J} 2$ antibody (mouse monoclonal from Englsih and Scientific Consulting)

please search: scicrunch.org/resources/Any/search?q=J2

A secondary anti-mouse antibody labeled with Alexa 488 fluorophore

please search: scicrunch.org/resources/Any/search?q=Alexa

Uninfected C57BI/6 mice

please search: scicrunch.org/resources/Any/search?q=C57BI/6

Please consider adding each research resource highlighted above against the identifier and add the syntax visible in the "cite this" button to the final version of the paper. Note, searching with the catalog number is often the most effective method of quickly finding the RRID.

Kind regards,

Anita

Competing Interests: I am testing a new tool for methods review. 
The benefits of publishing with F1000Research:

- Your article is published within days, with no editorial bias

- You can publish traditional articles, null/negative results, case reports, data notes and more

- The peer review process is transparent and collaborative

- Your article is indexed in PubMed after passing peer review

- Dedicated customer support at every stage

For pre-submission enquiries, contact research@f1000.com 